\title{
Pendekatan Multilevel Sebagai Upaya Meningkatkan Pemberian ASI Eksklusif
}

\author{
Nur Khamidah ${ }^{1^{*}}$, Yayi Suryo Prabandari ${ }^{2}$, Detty Siti Nurdiati ${ }^{3}$ \\ Public Health Departement, Faculty of Medicine, Wijaya Kusuma Surabaya University ${ }^{1}$ \\ Health Behavior and Health Promotion, Postgraduate Program, Faculty of Medicine, \\ University of Gadjah Mada² \\ Obstetric and Gynecology Department (Obgyn), Sardjito General Hospital, University of \\ Gadjah Mada ${ }^{3}$ \\ *email: nurkhamidah2006@gmail.com
}

\begin{abstract}
Abstrak
Upaya meningkatkan pemberian air susu ibu (ASI) terus menerus dilakukan di Kabupaten Jember, Pemerintah daerah setempat bekerjasama dengan USAID untuk meningkatkan program promosi kesehatan. Program promosi kesehatan yang dilakukan menggunakan pendekatan multilevel. Penelitian ini bertujuan untuk melakukan evaluasi program pemberian ASI eksklusif dan dampak program terhadap peningkatan pemberian ASI eksklusif di Wilayah Kabupaten Jember, Provinsi Jawa Timur. Metode penelitian ini menggunakan pendekatan cross sectional dua populasi dengan menggunakan mix methods (kualitatif dan kuantitatif). Data kualitatif menggunakan observasi partisipatif, wawancara mendalam dan FGD (focus group discussion) untuk menggambarkan program. Data kuantitatif dikumpulkan dengan lembar kuesioner untuk evaluasi dampak program pada dua populasi (120 responden program dan 125 responden non program). Data kualitatif dianalisis menggunakan open code, sedangkan analisis data kuantitatif menggunakan uji chi square. Hasil Penelitian menunjukkan bahwa promosi kesehatan dapat meningkatkan pemberian ASI eksklusif menggunakan pendekatan mulitilevel. Pada level atas, implementasai program melalui kebijakan Peraturan Bupati no. 17 tahun 2013 tentang persalinan aman, inisiasi menyusui dini dan pemberian ASI eksklusif. Pada level menengah, implementasi program dengan dinas kesehatan dan Puskesmas melalui pendekatan kelompok, kelas ibu hamil dan promosi oleh bidan. Pada level bawah hasil evaluasi dilakukan pada dua kelompok program dan non program menunjukan perbedaan signifikan secara statistik. Kelompok yang mendapat program memiliki 2,4 nilai OR yang lebih tinggi dibandingkan kelompok yang tidak mendapat program. Berdasarkan penelitian ini dapat disimpulkan bahwa pendekatan multilevel dapat digunakan untuk meningkatkan pemberian ASI eksklusif hingga 6 bulan. Dukungan pemerintah dibutuhkan untuk keberhasilan program.
\end{abstract}

Kata kunci: Evaluasi pemberian ASI, ASI eksklusif, Inisiasi menyusu dini, program promosi ASI

\section{Multilevel Approach to Increase Exclusive Breastfeeding}

\begin{abstract}
Increasing exclusive breastfeeding effort was continued in Jember district. Local government collaborates with USAID to increase breastfeeding promotion program. Health promotion program used multilevel approach. This study aimed to evaluate exclusive breastfeeding program and impact program to increasing breastfeeding in Jember district. This study method
\end{abstract}


used cross sectional study in two population with mix method approach (qualitative and quantitative). Collecting qualitative data was using participative observation, indepth interview and focus group discussion to describing program. Collecting quantitative data was using questionare to evaluate impact program in two populations (120 respondent program and 125 respondent non program). Data was analyzed by open code in qualitative data. To analyzed quantitative data was used chi square. The research result shows that Health promotion program increased exclusive breastfeeding was using multilevel approach. In top level, implementation of the program was regulation government policy number 17, 2013 about save childbirth, initiation breastfeeding and exclusive breastfeeding. In the middle level implementing program by Jember health department and local government clinic through peer breastfeeding support, mother pregnant class and promote by midwife. Lower level evaluation result was that two population program and non program have different significant. Population who give program have 2,4 higher OR value in exclusive breastfeeding than population not give the program. Based on this research it can be concluded that multilevel approach can used to increasing exclusive breastfeeding until six month. Government support was needed to successful program.

Keywords: breastfeeding evaluation, exclusive breastfeeding, initiation breastfeeding, breastfeeding promotion program

\section{PENDAHULUAN}

Air susu ibu (ASI) dalah makanan yang terbaik untuk bayi. Nutrisi yang terkandung dalam ASI terbukti paling lengkap dan sesuai dengan kebutuhan bayi. Namun, manfaat tersebut tidak dapat menyadarkan ibu untuk bersedia memberikan ASI eksklusif hingga 6 bulan seperti yang direkomendasikan WHO. Pemberian ASI eksklusif hingga bayi berusia 6 bulan saat ini kurang dari 38\% di seluruh dunia (WHO, 2014). Data Riset Kesehatan Dasar (Riskesdas) tahun 2010, persentase bayi yang menyusui ASI eksklusif yang berdasarkan definisi WHO sampai dengan 6 bulan di Indonesia hanya sebesar 15,3\% (Kemenkes, 2010) Kajian Riskesdas terbaru tahun 2012, bayi yang hanya diberi ASI hingga usia 6 bulan sebesar 30,2\%
(Kemenkes, 2013). Data SDKI tahun 2012 menunjukkan data yang tidak jauh berbeda dengan Riskesdas 2012 untuk pola pemberian ASI. Pada bayi yang diberikan ASI secara eksklusif hingga berusia kurang dari 6 bulan sebesar 27,1\% (SKDI, 2013).

Secara global, program promosi ASI dimulai sejak tahun 1970an, digalakkan kembali pada tahun 1989 dengan deklarasi innocent. Setelah deklarasi tersebut, semua rumah sakit maupun klinik bersalin dihimbau untuk turut mempromosikan pemberian ASI eksklusif (Riordan, 2010). Program yang menjadi anjuran dari WHO adalah 10 langkah keberhasilan menyusui yang ditujukan pada rumah sakit ataupun klinik bersalin dengan program "baby friendly hospital". Program tersebut lebih ditujukan pada kebijakan rumah sakit 
maupun klinik bersalin agar ikut berperan serta mewujudkan keberhasilan pemberian ASI eksklusif. Saat ini telah banyak negara yang mengadopsi kebijakan tersebut. Berdasarkan hasil evalusai diketahui bahwa terdapat peningkatan pemberian ASI pada daerah yang terdapat program tersebut dibandingkan dengan rumah sakit atau klinik yang tidak menerapkan program tersebut (Howell et al, 2014).

Berbagai macam pendekatan program telah dilakukan untuk meningkatkan pemberian ASI eksklusif, seperti yang telah dilakukan di rumah sakit Inggris (UK). Program yang dilaksanakan adalah "peer education for breastfeeding". Selain kebijakan rumah sakit, program promosi ASI juga dilakukan melalui peningkatan kemampuan tenaga kesehatan, pendekatan kelompok dan kombinasi antara program untuk tenaga kesehatan dan kelompok. Hasil penelitian menunjukan bahwa kombinasi tenaga kesehatan dan kelompok dapat memperlama durasi pemberian ASI (Jolly et al, 2012).

$\mathrm{Di}$ Indonesia, program untuk meningkatkan pemberian ASI eksklusif hingga bayi berusia 6 bulan secara terus menerus dilakukan baik melalui promosi dan juga penerbitan peraturan pemerintah (PP) tentang ASI eksklusif. Kabupaten Klaten merupakan kabupaten pertama yang menerbitkan perda tentang ASI. Untuk melaksanakan perda, salah satu upaya yang dilakukan adalah melarang iklan susu formula dan lebih meningkatkan promosi ASI eksklusif. Berdasarkan hasil studi, diketahui bahwa program yang telah dilaksanakan dapat meningkatkan pemberian ASI eksklusif sebesar 79,9\% pada tahun 2011 (Asriani, 2012) Pendekatan multilevel juga dilakukan di Kabupaten Demak. Pendekatan yang dilakukan adalah dengan modifikasi lingkungan sosial pada level individu, antar individu dan masyarakat. Hasil studi menunjukkan bahwa pendekatan multilevel dapat memperlama durasi menyusui dan meningkatkan prevalensi pemberian ASI eksklusif (Susiloretni et al, 2013).

Sebagai salah satu upaya untuk meningkatkan pemberian ASI eksklusif di Kabupaten Jember, pemerintah Kabupaten Jember telah melakukan kerjasama dengan USAID. Secara umum kerjasama tersebut bertujuan untuk mengatasi masalah kesehatan, salah satu tujuannya adalah untuk promosi pemberian ASI eksklusif hingga 6 bulan berdasarkan rekomendasi WHO. Program promosi peningkatan ASI eksklusif masuk dalam program yang berjudul "Bantuan Teknis Program Pelayanan Persalinan Aman, Inisiasi Menyusu Dini (IMD) dan ASI Eksklusif 
Pendekatan Multilevel Sebagai Upaya Meningkatkan Pemberian ASI Eksklusif

Nur Khamidah, Yayi Suryo Prabandari, Detty Siti Nurdiati

Secara Transparan, Partisipatif dan

Akuntabel". Fokus program adalah untuk mengatasi masalah tingginya persalinan yang dilakukan oleh dukun, pelaksanaan IMD dan peningkatan pemberian ASI eksklusif. Program kegiatan untuk meningkatkan cakupan ASI eksklusif menjadi salah satu fokus program, namun pelaksanaan kegiatan juga bertujuan untuk mengatasi masalah penolong persalinan oleh dukun dan promosi IMD. Program yang dilakukan untuk mengatasi masalah tersebut menggunakan pendekatan multilevel, yakni pendekatan dengan modifikasi lingkungan dengan menyasar individu, antar individu dan masyarakat (Glanz et al, 2008).

Kerjasama dengan USAID telah dimulai pada tahun 2012 dan berlangsung selama 2 tahun. Saat ini program telah berakhir dan belum pernah dilakukan evaluasi. Oleh karena itu, tujuan penelitian ini adalah untuk melihat gambaran program promosi ASI eksklusif di Kabupaten Jember dan dampak program terhadap perilaku pemberian ASI eksklusif.

\section{METODE PENELITIAN}

\section{Jenis penelitian dan pengambilan sampel}

Penelitian ini merupakan penelitian observasional menggunakan metode cross sectional (Rallis \& Rossman, 2010). Strategi pengumpulan data menggunakan metode campuran (mix method). Metode campuran yang digunakan adalah metode campuran konkuren atau 1 waktu. Lokasi peneliitian dilakukan di 4 puskesmas yang ada di Kabupaten Jember, yakni Puskesmas Silo dan Mayang sebagai daerah intervensi program dan Puskesmas Kaliwates dan Sukorambi sebagai daerah kontrol. Pengumpulan data dilakukan melalui observasi partisipatif, wawancara mendalam pada 2 orang bidan dan 1 orang pemegang program dinas kesehatan. Selain itu juga dilakukan FGD pada kelompok masyarakat. FGD dilakukan 2 kali, yang pertama dilakukan di Kecamatan Mayang dan dihadiri 7 orang anggota forum peduli kelompok (FPK). FGD kedua dilakukan di Kecamatan Silo dan dihadiri 5 orang anggota FPK. Forum peduli kelompok (FPK) adalah perkumpilan tokoh masyarakat yang telah dibentuk oleh masyarakat setempat yang difasilitasi oleh USAID. Proses pengumpulan data kuantitatif dilakukan untuk mengetahui dampak program dengan membandingkan 2 kelompok daerah yang mendapat intervensi program dengan kelompok yang tidak mendapat intervensi. Jumlah responden penelitian untuk daerah yang mendapat program sebanyak 120 responden, sedangkan kelompok yang tidak mendapat program sebanyak 125 responden. Perhitungan jumlah responden 
dengan menggunakan software sample size dengan nilai $\mathrm{p} 1$ sebesar 0,3 dan $\mathrm{p} 2$ sebesar 0,5 dan tingkat kepercayaan 95\%. Responden pengumpulan data secara kuantitatif adalah ibu yang memiliki bayi berusia kurang dari 1 tahun dan tinggal dilokasi yang menjadi lokasi penelitian.

\section{Proses pengumpulan data}

Proses pengumplan data dimulai dengan observasi lokasi penelitian, melakukan identifikasi wilayah yang menjadi kontrol. Setelah teridentifikasi lokasi yang menjadi wilayah penelitian, tahap selanjutnya adalah melihat data bayi yang ada pada buku besar di tiap-tiap posyandu. Berdasarkan data tersebut, diidentifikasi calon responden kemudian dipilih calon responden yang memenuhi kriteria untuk selanjutnya dilakukan wawancara. Responden yang tidak hadir pada saat posyandu, wawancara dilakukan di rumah responden dengan didampingi kader, Wawancara dilakukan hingga kuota terpenuhi. Selain melakukan wawancara, peneliti juga melakukan observasi daerah lokasi penelitian untuk melihat gambaran perilaku masyarakat. Setelah data terpenuhi, tahap selanjutnya adalah pengumpulan data kualitatif melalui FGD dan wawancara mendalam pada bidan serta pemegang program terkait dengan ASI eksklusif. Setelah semua data terkumpul, wawancara terakhir dilakukan pada pihak dinas kesehatan untuk mengetahui gambaran umum program promosi ASI eksklusif yang pernah dilakukan di Kabupaten Jember. Setelah semua data terkumpul, dilakukan analisis data. Analisis data kualitatif menggunakan software open code, sedangkan analisis data kuantitatif menggunakan uji chi square untuk membandingkan 2 variabel. Analisis data dilakukan dengan menggunakan software stata versi 12 .

\section{HASIL}

\section{Analisis perbedaan kelompok intervensi dibandingkan dengan kontrol}

Tabel 1. Karakteristik responden daerah yang mendapat program dibandingkan yang tidak mendapat program

\begin{tabular}{|c|c|c|c|c|c|c|c|}
\hline \multirow{2}{*}{\multicolumn{2}{|c|}{ Variabel }} & \multicolumn{6}{|c|}{ Daerah } \\
\hline & & \multicolumn{2}{|c|}{ program $(n=120)$} & \multirow[t]{2}{*}{$\%$} & \multicolumn{2}{|c|}{ Non program $(n=125)$} & \multirow[t]{2}{*}{$\%$} \\
\hline \multicolumn{6}{|l|}{ Usia } & & \\
\hline- & $<20$ th & 15 & 12,5 & & 12 & 9,6 & \\
\hline- & $20-29$ th & 64 & 53,3 & & 65 & 52,0 & \\
\hline- & $30-39$ th & 36 & 30,0 & & 42 & 33,6 & \\
\hline- & $>39$ th & 5 & 4,17 & & 6 & 4,8 & \\
\hline \multicolumn{8}{|c|}{ Tingkat pendidikan: } \\
\hline- & $\begin{array}{l}\text { Dasar (SD atau } \\
\text { SMP) }\end{array}$ & 39 & 32,5 & & 39 & 31,2 & \\
\hline
\end{tabular}


Pendekatan Multilevel Sebagai Upaya Meningkatkan Pemberian ASI Eksklusif

Nur Khamidah, Yayi Suryo Prabandari, Detty Siti Nurdiati

\begin{tabular}{clcccc}
\hline & Variabel & \multicolumn{5}{c}{ Daerah } \\
\cline { 2 - 5 } & program (n=120) & \% & Non program (n=125) & \% \\
\hline - & SMA & 71 & 59,2 & 75 & 60,0 \\
- & Perguruan tinggi & 10 & 8,3 & 11 & 8,8 \\
Pekerjaan & & & & 16 \\
- & Bekerja & 9 & 7,5 & 12,8 \\
- & Tidak bekerja & 111 & 92,5 & 109 & 87,2 \\
\hline
\end{tabular}

Tabel 1 adalah tabel analisis univariabel untuk menunjukkan distribusi responden berdasarkan karekteristik individu. Berdasarkan tabel di atas, diketahui bahwa sebagian besar responden baik kelompok intervensi program maupun kelompok yang tidak mendapat program berada pada rentang usia 20-29 tahun. Mayoritas responden mengaku pendidikan yang pernah ditempuh adalah kategori menengah, yakni SMP dan SMA dan sebagian besar responden tidak bekerja. Nilai p pada kelompok program maupun kelompok non program lebih besar dari 0,05 Artinya, tidak ada perbedaan berdasarkan karakteristik responden antara kelompok intervensi program maupun yang non program.

Tabel 2. Riwayat kelahiran responden daerah yang mendapat program dibandingkan dengan yang tidak mendapat program

\begin{tabular}{|c|c|c|c|c|c|c|}
\hline \multirow{2}{*}{\multicolumn{2}{|c|}{ Variabel }} & \multicolumn{2}{|c|}{ Program } & \multicolumn{2}{|c|}{ Non program } & \multirow[t]{2}{*}{$\mathbf{P}$} \\
\hline & & $N(120)$ & $\%$ & $N(125)$ & $\%$ & \\
\hline \multicolumn{7}{|c|}{ Pengalaman menyusui } \\
\hline- & Ada pengalaman & 57 & 47,5 & 63 & 50,4 & \multirow[t]{2}{*}{0,65} \\
\hline- & Tidak ada & 63 & 52,5 & 62 & 49,6 & \\
\hline \multicolumn{7}{|c|}{ Jenis Kelahiran } \\
\hline- & Primipara & 60 & 50,0 & 57 & 45,6 & \multirow[t]{2}{*}{0,49} \\
\hline- & Multipara & 60 & 50,0 & 68 & 54,4 & \\
\hline \multicolumn{7}{|c|}{ Penolong Persalinan } \\
\hline- & Dokter & 14 & 82,5 & 15 & 12,0 & \multirow[t]{3}{*}{0,21} \\
\hline- & Bidan & 99 & 11,7 & 108 & 86,4 & \\
\hline- & Dukun & 7 & 5,8 & 2 & 1,6 & \\
\hline \multicolumn{7}{|c|}{ Jenis Persalinan } \\
\hline- & Normal & 102 & 85,0 & 108 & 86,4 & \multirow[t]{2}{*}{0,75} \\
\hline- & Caesar & 18 & 15,0 & 17 & 13,6 & \\
\hline \multicolumn{7}{|c|}{ Pertama kali menyusui } \\
\hline- & $<1$ jam & 68 & 56,7 & 56 & 44,8 & \multirow[t]{5}{*}{0,25} \\
\hline- & 1 - 6 jam & 30 & 25,0 & 32 & 25,6 & \\
\hline- & $7-23$ jam & 7 & 5,8 & 9 & 7,2 & \\
\hline - & $24-48$ jam & 8 & 6,7 & 14 & 11,2 & \\
\hline- & $>48$ jam & 7 & 5,8 & 14 & 11,2 & \\
\hline
\end{tabular}

Tabel 2 adalah tabel analisis bivariate riwayat kelahiran terakhir pada 125 orang ibu rumah tangga pada kelompok non program dan 120 orang pada wilayah program. Uji statistik yang digunakan adalah chi square dengan $p$ value $<0,05$. 
ISSN 1978-2071 (Print); ISSN 2580-5967 (Online) Jurnal Ilmiah Kedokteran Wijaya Kusuma 10(1) : 45-56, Maret 2021

Hasil uji statistik tidak ada perbedaan bermakna kelompok program maupun non program pada variabel pengalaman menyusui, jenis kelahiran, penolong persalinan, jenis persalinan dan waktu pertama kali menyusui. Berdasarkan tabel di atas juga menunjukkan bahwa masih ada penolong persalinan yang dibantu oleh dukun baik pada kelompok program maupun non program.
Untuk mengetahui dampak program berdasarkan sumber paparan informasi mengenai ASI dan menyusui pada daerah yang mendapat program dibandingkan dengan yang tidak mendapat program, dilakukan analisis chi square dengan nilai kemaknaan alpha $<0,05$ untuk membandingkan paparan informasi yang diperoleh pada masa kehamilan, saat melahirkan dan pasca melahirkan. Hasil analisis adalah sebagai berikut:

Tabel 3. Analisis bivariate perbedaan paparan sumber informasi kelompok program dibandingkan dengan kelompok non program

\begin{tabular}{|c|c|c|c|c|c|c|}
\hline \multirow{3}{*}{\multicolumn{2}{|c|}{ Variabel }} & \multicolumn{4}{|c|}{ Daerah } & \multirow[t]{3}{*}{$\mathbf{P}$} \\
\hline & & \multicolumn{2}{|c|}{ Program } & \multicolumn{2}{|c|}{ Non program } & \\
\hline & & $\mathrm{N}(120)$ & $\%$ & $N(125)$ & $\%$ & \\
\hline \multicolumn{7}{|c|}{ Pemeriksaan kehamilan } \\
\hline & $\mathrm{Ya}$ & 87 & 72,5 & 92 & 73,6 & 0.84 \\
\hline & Tidak & 33 & 27,5 & 33 & 26,4 & \\
\hline \multicolumn{7}{|c|}{ Pasca persalinan } \\
\hline . & Ya & 89 & 74,2 & 90 & 72 & 0.70 \\
\hline & Tidak & 31 & 25,8 & 35 & 28 & \\
\hline \multicolumn{7}{|c|}{ Media } \\
\hline  & $\mathrm{Ya}$ & 78 & 65 & 82 & 34,4 & 0.92 \\
\hline & Tidak & 42 & 35 & 43 & 65,6 & \\
\hline \multicolumn{7}{|c|}{ Keluarga } \\
\hline . & $\mathrm{Ya}$ & 81 & 67,5 & 99 & 79,2 & $0.03 *$ \\
\hline & Tidak & 39 & 32,5 & 26 & 20,8 & \\
\hline \multicolumn{7}{|c|}{ Kelompok masyarakat } \\
\hline- & Ya & 67 & 55,8 & 54 & 43,2 & $0.04^{*}$ \\
\hline & Tidak & 53 & 44,2 & 71 & 56,8 & \\
\hline \multicolumn{7}{|c|}{ Keinginan sendiri } \\
\hline . & $\mathrm{Ya}$ & 29 & 24,2 & 59 & 47,2 & $0.00^{*}$ \\
\hline . & Tidak & 91 & 75,8 & 66 & 52,8 & \\
\hline
\end{tabular}

$*_{\text {nilai }} \mathrm{p}<0,05$ (significant)

Tabel 3 menunjukkan hasil analisis bivariate dengan variabel independen program dibandingkan dengan variabel dependen sumber paparan informasi tentang ASI. Paparan informasi berasal dari tenaga kesehatan serta informasi dari luar seperti media, keluarga, kelompok masyarakat dan keinginan sendiri. Berdasarkan hasil uji statistik perbedaan bermakna pada variabel paparan informasi dari keluarga ( $p$ value 0,030), kelompok masyarakat ( $p$ value 0.040 ) dan keinginan 
Pendekatan Multilevel Sebagai Upaya Meningkatkan Pemberian ASI Eksklusif

Nur Khamidah, Yayi Suryo Prabandari, Detty Siti Nurdiati

sendiri ( $p$ value 0.000). Paparan informasi pada masa kehamilan, pasca lahir dan media tidak ada perbedaan bermakna secara statistik. Artinya, paparan informasi kelompok intervensi dan program 0sama. Paparan informasi secara statistik memiliki hubungan bermakna adalah sumber informasi yang berasal dari kelurga, kelompok masyarakan dan keinginian sendiri yang memiliki nilai $p<0,05$. Artinya, terdapat perbedaan paparan informasi pada kelompok program dan non program.

Deskripsi program promosi ASI eksklusif Kabupaten Jember

Berdasarkan hasil pengumpulan data baik data primer maupun data sekunder, program promosi ASI eksklusif di Kabupaten Jember secara khusus tidak berdiri sendiri. Pelaksanaannya tergabung dalam program-program yang diadakan di dinas kesehatan yang bertujuan akhir untuk meningkatan cakupan ASI eksklusif. Sasaran implementasi program multilevel, yakni individu, antar individu dan masyarakat. Strategi yang digunakan adalah dengan modifikasi lingkungan melalui advokasi peraturan bupati (Perbup) pada level pemerintah. Membantu pelaksanaan perbup pada level menengah. Pada level tersebut yang bertindak sebagai pelaku adalah dinas kesahatan, puskesmas dan tenaga kesehatan. Pada tingkat bawah, intervensi yang dilakukan adalah langsung kepada masyarakat. Berikut adalah hasil analisis bivariate dengan membandingkan ibu yang memberikan ASI pada daerah yang mendapat program, dibandingkan dengan yang tidak mendapat program:

Tabel 4. Analisis bivariate perilaku memberikan IMD dan ASI eksklusif kelompok intervensi dibandingkan kontrol

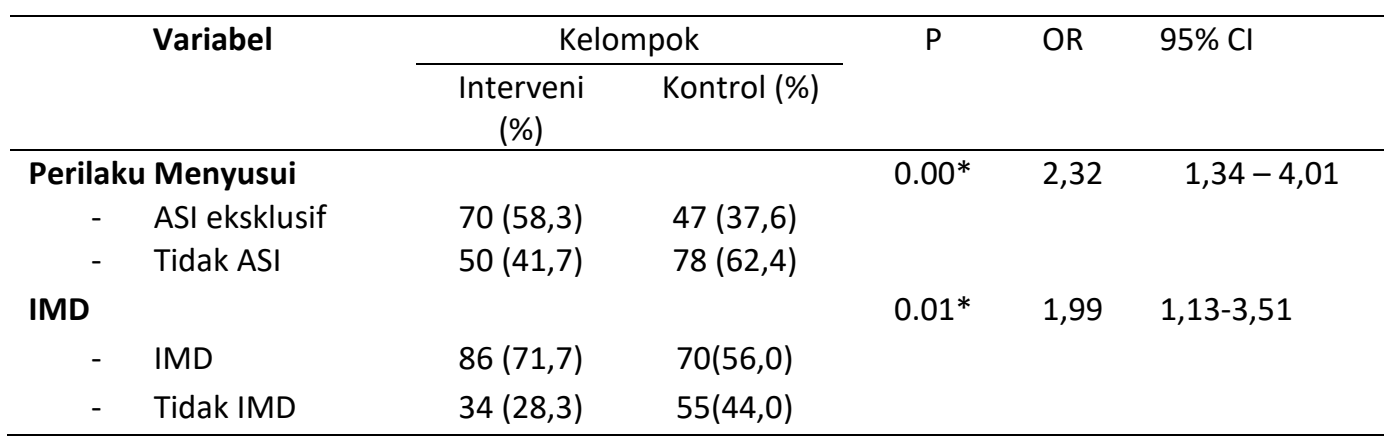

*nilai $\mathrm{p}<0,05$ (significant)

Tabel 4 menunjukkan hasil pengujian untuk membandingkan perilaku pemberian ASI eksklusif dan IMD kelompok intervensi dibandingkan kelompok kontrol. ASI eksklusif dan IMD sebagai variabel dependen, program adalah variabel independen. Nilai $\mathrm{p}$ pada variabel perilaku pemberian ASI eksklusif sebesar 0,001 dengan nilai OR 2,32 dan confident interval 1,34 - 4,01. Artinya secara statistik dan 
praktis terdapat perbedaan bermakna. Nilai OR menunjukkan kelompok yang mendapat program melakukukan ASI ekslusif 2,32 kali dibandingkan dengan kelompok yang tidak mendapat intervensi program. Bayi yang melakukan IMD sesuai dengan definisi perbub, yakni bayi diletakkan di dada setelah lahir dan dibiarkan mencari puting sendiri selama 1 jam memiliki nilai $\mathrm{p} 0,01$ dengan nilai $O R$ 1,99 dan confident interval 1,13 - 3,51. Artinya, secara statistik dan praktis memiliki hubungan bermakna, kelompok yang memperoleh program melakukan IMD sebesar 1,99 kali dibandingkan dengan kelompok yang tidak mendapat program.

\section{PEMBAHASAN}

Secara nasional kebijakan untuk memberikan ASI eksklusif pada bayi diatur dalam PP No 33 Tahun 2012 (Perbup, 2013). PP tersebut telah disosialisasikan pada organisasi wanita dan rumah sakit yang ada di Kabupaten Jember. Dalam rangka upaya untuk memperkuat peraturan tersebut, Pemerintah Kabupaten Jember telah mengesahkan Perbup no 17 tahun 2013 dengan topik yang lebih luas yakni untuk persalinan aman, IMD dan ASI eksklusif. Proses pengesahan perbup tersebut dibantu oleh USAID dalam menyusun perbup. Pasal-pasal pada Perbup no 17 Tahun 2013 tentang
Pedoman Persalinan Aman, Inisiasi Menyusu Dini dan Pemberian ASI Eksklusif terdiri dari pasal-pasal yang memuat definisi, tanggung jawab, strategi promosi dan sanksi terkait IMD dan ASI. Salah satu isi yang tertuang dalam perbup adalah adanya pasal yang menjelaskan bahwa bayi berhak mendapat IMD dan ASI eksklusif, ibu berkewajiban melakukan IMD dan harus memberikan ASI eksklusif. Dinas kesehatan, rumah sakit, tenaga kesehatan dan fasilitas kesehatan memiliki tanggung jawab melaksanakan kegiatan yang tertuang dalam perbup tersebut dengan ikut membantu promosi (Perpu, 2012).

Kerangka teori CDC (Centre for Desease Control) adalah kerangka teori yang digunakan untuk evaluasi. Pada kerangka teori dimulai dengan menggabungkan stakeholder. Dalam analisis komunitas, selain melihat besaran masalah, juga dilakukan analisis sumberdaya yang terlibat dalam pelaksanaan program peningkatan pemberian ASI eksklusif. Berdasarkan hasil penelitian ini, dalam pelaksanaan program peningkatan pemberian ASI ekslusif ini stakeholder yang terlibat antara lain dinas kesehatan, bidan koordinator puskesmas dan tokoh masyarakat yang ada di tiap-tiap desa. Kerja sama stakeholder memiliki fungsi dalam membantu keberhasilan program. 
Pendekatan Multilevel Sebagai Upaya Meningkatkan Pemberian ASI Eksklusif

Nur Khamidah, Yayi Suryo Prabandari, Detty Siti Nurdiati

Bonet et al menyebutkan kebijakan untuk tiap wilayah harus spesifik dan disesuaikam berdasarkan karakteristik masing-masing daerah (Bonet et al., 2010). Peraturan tentang ASI ekslusif di Kabupaten Jember adalah peraturan yang secara spesifik dikeluarkan dalam upaya mengatasi masalah terkait kesehatan ibu dan anak. Green et al. (1980) dalam proceed model menjelaskan bahwa kualitas kehidupan dipengaruhi oleh kesehatan, dan kesehatan juga dipengaruhi oleh faktor perilaku individu, genetik dan lingkungan (Glanz et al, 2008). Teori prooced yang dikemukakan oleh Green mendukung hasil penelitian ini bahwa perilaku pemberian ASI dipengaruhi oleh banyak faktor, baik dalam faktor individu maupun lingkungan (Glanz et al, 2008).

Hasil analisis bivariat pada kelompok intervensi dan kontrol untuk paparan informasi tentang ASI, tidak ada perbedaan bermakna informasi mengenai ASI eksklusif pada saat pemeriksaan kehamilan, saat melahirkan dan informasi dari media. Artinya petugas kesehatan yang membantu persalinan di Kabupaten Jember turut memberikan informasi mengenai ASI dan mendukung pemberian ASI ekslusif baik pada saat pemeriksaan kehamilan maupun pada saat melahirkan. Data secara kualitatif juga mendukung hasil tersebut, disebutkan bahwa informasi mengenai ASI adalah protap yang harus dilaksanakan bidan pada kunjungan ke 4 dalam mewujudkan 1000 hari pertama kehidupan (HPK). Selain itu, setelah perpub disahkan dan disosialisasikan pada bidan dan tenaga kesehatan mengindikasikan bahwa isi perbup telah dilaksanakan, baik pada daerah yang mendapat bantuan program maupun yang tidak mendapat program. Hasil ini mendukung teori Green dalam proceed model yang menyebutkan bahwa kebijakan turut memberikan dampak terhadap perilaku (Bartholomew et al, 2006). Protap menjadi aturan yang harus dilakukan dalam melakukan standar memberikan pelayanan kesehatan pada ibu hamil. Bunock et al. menyatakan bahwa kunjungan pada saat prenatal dan postnatal dapat meningkatkan pemberian ASI (Bonuck et al., 2014).

Adanya bantuan program turut memberikan dampak terhadap pemberian ASI eksklusif. Secara statistik pada kelompok yang mendapat bantuan program menunjukkan nilai OR yang lebih tinggi untuk IMD dan ASI ekslusif dibandingkan dengan kelompok yang tidak mendapat program. Artinya adanya bantuan program dapat meningkatkan pemberian ASI. Program untuk meningkatkan pemberian ASI eksklusif di Kabupaten Jember yang menjadi wilayah intervensi adalah program yang 
menggabungkan pendekatan peer dan individu, sedangkan daerah yang menjadi kontrol, program yang dadakan hanya pendekatan peer atau individu. Pendekatan dengan menggabungkan kombinasi peer dan individu lebih memberikan dampak terhadap perilalaku pemberian ASI ekslusif. Terbukti dengan hasil penelitian bahwa daerah yang mendapat program akan memberikan ASI eksklusif hingga 6 bulan sebesar 2,4 kali dibandingkan daerah yang tidak mendapat program. Hasil penelitian ini mendukung pernyataan Haroon et al. (2013) yang menyatakan bahwa kombinasi pendekatan intervensi peer dan individu lebih efektif untuk meningkatkan pemberian ASI eksklusif hingga 6 bulan (Haroon et al, 2013).

\section{KESIMPULAN}

Program kerja sama antara USAID dengan pemerintah daerah Kabupaten Jember untuk promosi peningkatan pemberian ASI ekslusif dengan menggunakan pendekatan multilevel dapat meningkatkan pemberian IMD dan ASI eksklusif. Hasil analisis statistik menunjukan tidak adanya perbedaan sumber informasi dari petugas kesehatan saat pemeriksaan kehamilan dan pada saat melahirkan mengindikasikan dampak perbup terhadap promosi ASI yang dilakukan oleh tenaga kesehatan.

\author{
Kelemahan dalam penelitian ini tidak \\ mengukur faktor-faktor lain yang \\ mempengaruhi IMD dan ASI eksklusif, \\ sehingga kemungkinan terjadi bias \\ informasi.
}

\section{DAFTAR PUSTAKA}

Asriani DD dan Itriyati F, 2008. Gerakan Inisiasi Menyusui Dini dan Pemberian ASI Eksklusif Kabupaten Klaten. http://igi.fisipol.ugm.ac.id.

Bartholomew LK, Parcel GS, Kok G, and Gottlieb NH, 2006. Planning Health Promotion Programs. San Fransisco: Jossey Bass.

Bonet M, Blondel B, \& Khoshnood B, 2010. Evaluating Regional Differences in Breast-Feeding in French Maternity Units: A Multi-Level Approach. Public Health Nutrition Journal. 13(12): 1946-1954.

Bonuck K, Stuebe A, Barnett J, Labbok MH, Fletcher J and Bernstein PS, 2014. Effect of Primary Care Intervention on Breastfeeding Duration and Intensity. American Journal of Public Health.104:119127.

Kemenkes, 2010. Riset Kesehatan Dasar 2010. Jakarta: Departemen Kesehatan Indonesia. 
Pendekatan Multilevel Sebagai Upaya Meningkatkan Pemberian ASI Eksklusif

Nur Khamidah, Yayi Suryo Prabandari, Detty Siti Nurdiati

Kemenkes, 2013. Riset Kesehatan Dasar

2013. Jakarta: Departemen Kesehatan Indonesia.

BPS, BKKBN, \& Kemenkes, 2012. Survei Demografi dan Kesehatan Indonesia. Jakarta: Litbang.

Glanz K, Rimer BK, \& Viswanath K, 2008. Health Behavior and Health Education: Theory, Research and Practise. San Fransisco: Jossey Bass.

Haroon S, Das JK, Salam RA, Imdad, A., and Bhuta ZA, 2013. Breastfeeding Promotion Interventions and Breastfeeding Practice: A Systematic Review. BMC Public Health. 13(Suppl 3): S20.

Howell EA, Deren SB, Balbierrz A, Parides M, and Bickel N, 2014. An
Intervention to Extend
Breastfeeding among Black and
Latina Mother After Delivery.
American Journal of Obstetric and
Gynecology. 210-215. Jolly K, Ingram L, Freemantle N, Chambers

J, Khan K, and Brown J, 2012. Effect of Peer Support Service on Breastfeeding Continuation in the UK: a Randomized Control Trial . Journal of Midwefery Elsevier. 740-745.

Rallis SF, \& Rossman GB, 2010. Metode Campuran dalam Konteks
Evaluasi: Sebuah Kerangka Pragmatik. In A. Tashakkori, \& C. Teddlie, Handbook of Mixed Methods In Social \& Behavioral Research (Edisis Bahasa Indonesia). pp. 441-458. California: Pustaka Pelajar.

Riordan J, 2010. The Biological Spesificity of Breastmilk. In J. Riordan, \& K. Wambach, Breastfeeding and Human Lactation. pp. 134. Boston: Jones and Bartlett Publisher.

Susiloretni K, Krisnamurni, Sunarto, Widiyanto S, Yazid A, dan Wilopo $S$, 2013. The Effectiveness of Multilevel Promotion of Exclusive Breastfeeding in Rural Indonesia. American Journal of Health Promotion. e44-e55.

Perbup, 2013. Peraturan Gubernur Kabupaten Jember Nomor 17 Tahun 2013 tentang Pedoman Persalinan Aman, Inisiasi menyusui Dini dan Pemberian ASI Eksklusif.

Perpu, 2012. Peraturan Pemerintah Republik Indonesia Nomor 33 Tahun 2012 tentang Pemberian Air Susu Ibu Eksklusif.

WHO, 2014. Infant and Young Child Feeding.http://www.who.int/med iacentre/factsheets/fs342/en/ 